\title{
Bioactivity Screening of Erechtites valerianifolia (Link Ex Wolf.) Less. Extracts as Antiplasmodium, Antibacterial, Antifungal and Cytotoxic Agents
}

\author{
A.R. Puspaningtyas ${ }^{1,2}$, S. Riyanto ${ }^{2}$, E.N. Solikhah ${ }^{3}$ and P. Astuti ${ }^{2}$ \\ ${ }^{1}$ Faculty of Pharmacy, Jember University, Jember-Indonesia \\ ${ }^{2}$ Faculty of Pharmacy, Universitas Gadjah Mada, Yogyakarta-Indonesia \\ ${ }^{3}$ Faculty of Medicine, Universitas Gadjah Mada, Yogyakarta-Indonesia
}

(Received: 13 May, 2017; Accepted: 26 December, 2017; Published (web): 10 June, 2018)

\begin{abstract}
Indonesia's rich natural resources have encouraged many researchers to explore their potential for finding treatment of endemic diseases and malignancy. One of these resources is Erechtites valerianifolia (Link Ex Wolf.) Less. Ex DC or "Jonggolan" (Indonesian name), a member of the family Asteraceae was collected from Meru Betiri Forest. Empirical evidence reveals the use of this plant to treat fever, diarrhea, tonsillitis, wounds, and eczema. A study in 2015 reported that the family Asteraceae passed the test of antioxidant and antibacterial activity. Yet, scientific information about E. valerianifolia has not been optimally explored, and studies of this plant are even very limited. Considering the background, this study was aimed to conduct bioactivity screenings of E. valerianifolia extracts as antiplasmodial, antibacterial, antifungal and was anticancer/cytotoxic agents. Extract was obtained through percolation method using hexane, dichloromethane, ethyl acetate, and methanol as the solvents. Gram positive bacteria (Staphylococcus aureus, Methicillin-resistant Staphylococcus aureus and Bacillus cereus) and gram negative bacteria (Escherichia coli and Pseudomonas aeruginosa) were used as the antibacterial testing microorganisms. Candida albicans was the antifungal testing microorganism. The results showed that extracts, at a concentration of maximum $1000 \mathrm{ppm}$, were less active than the positive-control amoxicillin for antibacterial activities and ketoconazole for antifungal agents. Inhibition zones of $E$. valerianifolia extracts were invisible when compared to the positive controls. The screening of antiplasmodial ( $P$. falciparum FCR3) activity indicated that $\mathrm{IC}_{50}$ of ethyl acetate extract was $117.122 \mu \mathrm{g} / \mathrm{ml}$ and was considered the best among other extracts. The cytotoxicity study on MCF 7 , WiDr and Hela cell lines showed that the four extracts tested had good cytotoxicity with $\mathrm{IC}_{50}<30 \mu \mathrm{g} / \mathrm{ml}$.
\end{abstract}

Key words: Erechtites valerianifolia, antiplasmodium, antibacterial, antifungal, cytotoxicity.

\section{INTRODUCTION}

Traditional medicine is a heritage that has been developed since ancient times, and Indonesia is one of the countries with potential medicinal plants, where the natural resources most widely used as medicine ingredients are herbs and have existed for centuries. Searching for potential plants in nature is one of the methods to obtain a new drug. ${ }^{1}$ Even though processing drugs from nature takes time, their adverse effects are relatively small. Indonesia's

Correspondence to: A.R. Puspaningtyas

Email: aixrose_pee@yahoo.co.id

Tel/Fax : 08123473390

Dhaka Univ. J. Pharm. Sci. 17(1): 1-8, 2018 (June) richness of natural resources has led a lot of researchers to investigate the potential of medicinal plants for endemic and malignancy disease treatment. Erechtites valerianifolia (Link Ex Wolf.) Less. Ex DC or locally named "Jonggolan", a member of the family Asteraceae, from Meru Betiri Forest is one of them. Located in Jember Regency, East JavaIndonesia, the forest is home to a large number of medicinal plants that function as vegetables to local communities. ${ }^{2}$ The local people are unaware that $E$. valerianifolia, the plant they consider as weed, is in fact a medicinal plant. However, empirical evidence confirms that this plant is commonly used to treat fever, diarrhea, tonsillitis, wounds, and eczema, and 
members of the family Asteraceae are generally efficacious as an antimalarial. The study reported that the extract of plants in Asteraceae family has antimalarial activity against various types of Plasmodium. ${ }^{3-5}$ In addition, a study in 2015 found that the extract of the family Asteraceae exhibits antioxidant and antibacterial activities. ${ }^{6,7}$ The mechanism of action of antibacterial drugs is slightly similar to that of antifungal drugs and antimalarial/antiplasmodium; therefore, it is hypothesized that $E$. valerianifolia is likely to possess both antifungal and antiplasmodium activities. The antioxidant activity conducted with anticancer/cytotoxic so it is hypothesized that $E$. valerianifolia is likely to possess cytotoxic activity. ${ }^{7,8}$

Infectious diseases remain to be the most common among the population of developing countries, including Indonesia. One of their causes is a bacterial infection. Pathogenic bacteria is more harmful and causes either sporadic or endemic infections, such as Escherichia coli, Methicillinresistant Staphylococcus aureus, Staphylococcus aureus, Bacillus subtillis, or Pseudomonas aeruginosa that cause diarrhea. ${ }^{9,10}$

Meanwhile, fungus thrives in tropical regions with high humidity like Indonesia. One of the pathogenic fungi causing an infection named vulvovaginal candidiasis in women is Candida albicans; its incidence rate reached $75 \%$ among Indonesian women. In addition, fungus can invade such other organs as the mouth, skin, nails, lungs, gastrointestinal tract, urinary tract, heart and brain membrane that cause fever. ${ }^{11}$

Malaria is a tropical disease widely spread in several regions in Indonesia. Most malaria endemic areas are outside Java, in which many malaria-prone tropical forests grow. During the period 2000-2004, the endemic rate of malaria in Indonesia indicated an increase. The Annual Parasite Incidence (API) in Indonesia from 1995 to 2008 per 1000 people rose rapidly, and in 2008 it even went up to 2.47. Extraordinary events of malaria in Indonesia attacked 15 provinces during the period 1998-2003. In 2011, the number of malaria deaths reported reached 388 cases. ${ }^{12-15}$ Malaria is a disease caused by Plasmodium with Plasmodium falciparum as a parasite with the most resistance rate. Efforts are underway for the treatment of malaria patients as well as prevention through malaria elimination initiatives. The high rate of malaria in Indonesia has led to a new issue: resistance to chloroquine as the first-line treatment for malaria. In 1990, cases of $P$ falciparum chloroquine resistance occurred in all provinces in Indonesia. Treatment of $P$. falciparum malaria, especially in Indonesia, initiated in 2012 according to the policy of The Indonesian Department of Health and WHO recommendation was required to use a new drug combination of artemisinin derivative known as artemisinin combination therapy (ACT). Artemisinin is an isolate of Artemisia annua (family Asteraceae). Treatment using a combination of drugs does not necessarily resolve malaria problems completely, considering that malaria epidemics spread faster. ${ }^{14,16-18}$

Cancer is malignant disease involving abnormal cell growth with the potential to invade or spread to other parts of the body. The development of cancer in the world is increasingly. Preliminary test of anticancer activity is cytotoxicity. The antioxidant activity conducted with anticancer/cytotoxic activity through reactive oxygen species (ROS) inhibition. ${ }^{7}$

A wide range of resistant antibacterial, antifungal, antiplasmodial and anticancer/cytotoxic drugs has recently been discovered. Scientific information and research about E. valerianifolia has not been optimally explored and highly limited so leading to obscure data about the bioactivity screening of E. valerianifolia as antiplasmodium, antibacterial, antifungal and cytotoxic activity. ${ }^{6,19-28}$

Based on empirical studies, this present research was aimed to conduct drug discovery through extraction of E. valerianifolia using a percolation method with hexane, dichloromethane, ethyl acetate, and methanol as the solvents followed by bioactivity screening against cancer cell lines, bacteria, fungus, and plasmodium. The plant E. valerianifolia can be seen in figure 1 . 


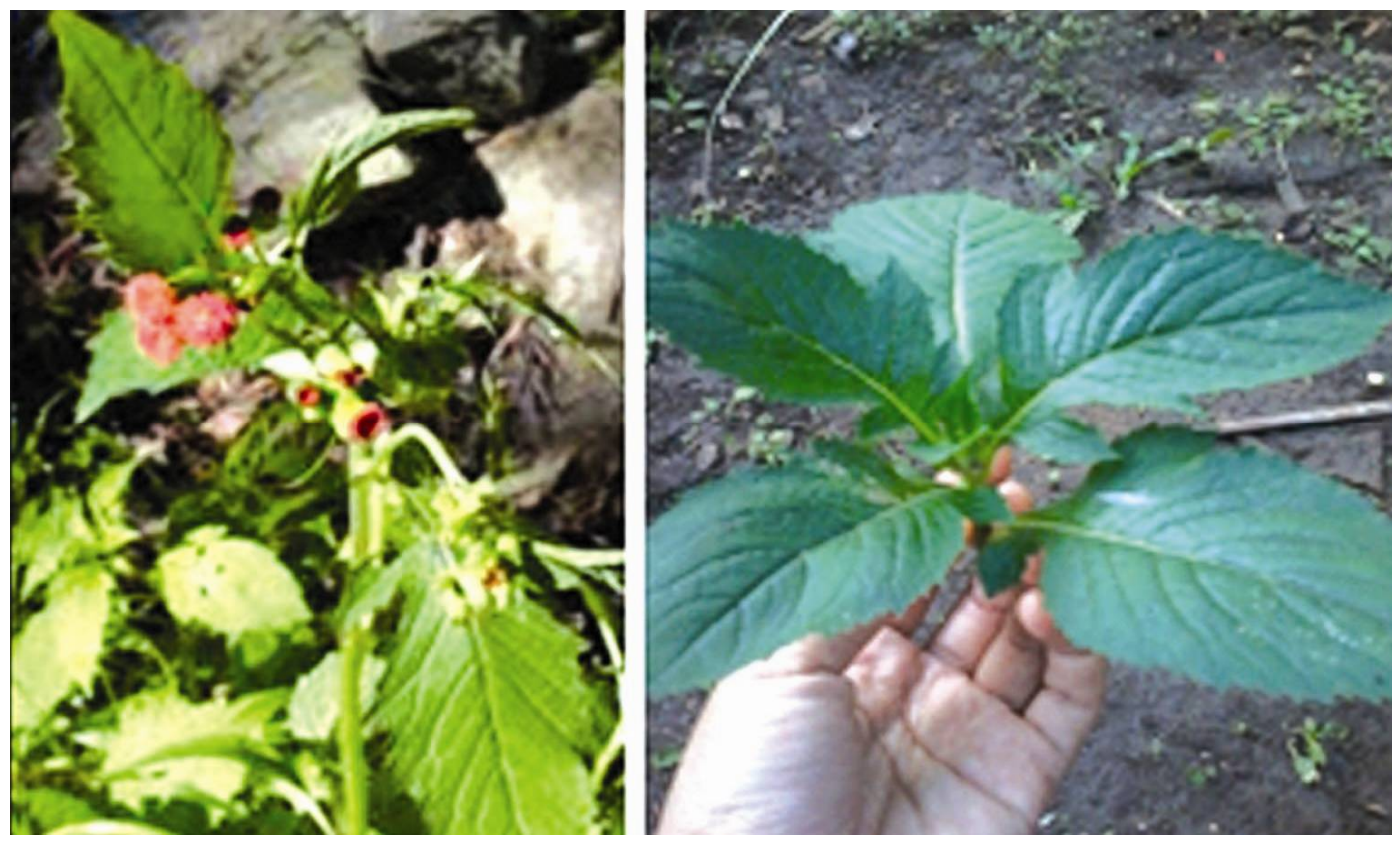

Figure 1. Erechtites valerianifolia (Link Ex Wolf.) Less. Ex DC.

\section{MATERIALS AND METHODS}

Materials: Escherichia coli, MRSA (Methicillinresistant Staphylococcus aureus), Staphylococcus aureus, Bacillus subtillis, and Pseudomonas aeruginosa, amoxicillin, hexane, dichloromethane, ethyl acetate and methanol of E. valerianifolia, C. albicans, potato dextrose agar (PDA) with 4 grams of potato content, 20 grams of dextrose, 15 grams of agar, ketoconazole, alcohol, wipes, sterile cotton, sterile distilled water, physiological saline and Muller-Hinton agar, chloroquine, P. falciparum FCR3 (chloroquine-resistant plasmodium), hydrogen peroxides in methanol, RPMI 1640, HEPES, sodium bicarbonate $90 \%$, hypoxanthine, gentamicine, aqua, $10 \%$ serum, $20 \%$ giemsa in aqua, physiological salt, AlbuMAX II (Invitrogen), ethanol, dimethyl sulfoxide (Fluka), giemsa stain, hydrogen peroxidase in methanol, normal goat serum, phosphate buffer saline (PBS) pH 7.4, Hela, WiDr, MCF-7 from Parasitology Laboratory Collection, Faculty of Medicine, Universitas Gadjah Mada, DMEM (Gibco), sodium bicarbonate (Sigma), hepes (Sigma), fetal bovine serum (FBS) $10 \%$ v/v (Gibco), penicillin-streptomycin $1 \% \mathrm{v} / \mathrm{v}$ (Gibco), fungisone
0,5\% v/v (Gibco), MTT: MTT ( 3-(4,5-dimethyl thiazole- 2-il (-2,5-diphenyl tetrazolium bromide))) $20 \mathrm{mg}, \mathrm{HCl} 0.01 \mathrm{~N}$ (Merck), 96-well plateand $\mathrm{H}_{2} \mathrm{O}$ buffer ( $\mathrm{pH}$ 6.8) were collected from appropriate sources and used in the experiments.

Extraction of E. valerianifolia. A total of $30 \mathrm{~kg}$ E. valerianifolia herb freshly obtained from Meru Betiri was dried at a low temperature $\left(50^{\circ}-70^{\circ} \mathrm{C}\right)$ to produce simplicia. Dry powder/simplicia was extracted using methanol, ethyl acetate, dichloromethane, and n-hexane by percolation method and evaporated using a rotary evaporator to obtain crude extract. ${ }^{29}$

Antibacterial activity. A total of 23 grams of Muller-Hinton agar powder was dissolved in sterile distilled water as much as $1000 \mathrm{ml}$. It was then heated to dissolve in an Erlenmeyer flask, plugged with fatty cotton and covered with aluminum foil and then sterilized by autoclaving at $121^{\circ} \mathrm{C}$ for 15 minutes. Potato dextrose agar (PDA) was weighed as much as $39 \mathrm{~g}$ then dissolved into $1 \mathrm{~L}$ of distilled water and heated on a hotplate-stirrer until boiling to form agar. As much as $5 \mathrm{ml}$ of the solution was put 
into test tubes for agar slopes and $15 \mathrm{ml}$ into sealed glass bottles for antifungal testing. The test tubes and sealed glass bottles containing agar were sterilized using an autoclave at $121^{\circ} \mathrm{C}$ for 20 minutes. E. coli, MRSA (Methicillin-resistant Stap. aureus), Stap. aureus, B. subtillis, and $P$. aeruginosa were planted in a nutrient agar (NA) growth mediumand incubated at $37^{\circ} \mathrm{C}$ for 24 hours. The bacteria to be tested were suspended by growing them in a liquid medium (physiological saline) and then incubated for 24 hours at $37^{\circ} \mathrm{C}$. Test fungi were cultured in prepared agar slopes and incubated at $30^{\circ} \mathrm{C}$ for 1 day. C. albicans was suspended in $3 \mathrm{ml}$ of physiological saline. In the antibacterial and antifungal activity test, the agar well diffusion method was used. A total of $200 \mathrm{ml}$ of each suspension of bacteria and fungi was added to $20 \mathrm{ml}$ of Nutrient Agar (NA) medium for bacteria and fungi. The mixture was rotated to be homogeneous, cooled and solidified in a sterile petridish. Wells with $\pm 6 \mathrm{~mm}$ diameter were formed using a perforator and $50 \mathrm{ml}$ of each extract (sample) and positive control dissolved in sterile distilled water were added into the wells. Preincubation was performed for 30 minutes at room temperature before the test. Incubation was carried out at $37^{\circ} \mathrm{C}$ for $48 \mathrm{hrs}$ for bacteria and fungi. Zone of inhibition was observed and measured using a slide caliper at the end of incubation period. The positive control used was amoxicillin for antibacterial and ketoconazole for antifungal screening. MIC determination was undertaken using agar dilution method. Test samples with different concentrations were added into $19 \mathrm{ml}$ of diluted agar media in a sterile petridish. The solution was mixed to obtain a homogeneous mixture and cooled to reach a solid state. A total of 1 dose of bacteria and fungi suspension was then inoculated on a surface of solid agar and then incubated at $37^{\circ} \mathrm{C}$ for 48 hours for bacteria and fungi. ${ }^{9,10,30}$

Antiplasmodium activity. P. falciparum FCR3 (chloroquine-resistant plasmodium) was obtained from Eikjman Jakarta-Indonesia. The ampoule containing falciparum strains was taken from a nitrogen tube and then heated in a water bath at $37^{\circ} \mathrm{C}$ to obtain liquid form. The ampoule content was transferred to a conical tube and $3.5 \% \mathrm{NaCl}$ was added drop wise with a ratio of 1:1 and shaken. As much as $10 \mathrm{ml}$ of RPMI was added and the mixture was centrifuged at $7000 \mathrm{rpm}$ for 10 minutes. The supernatant was discarded, and RPMI and human serum type $\mathrm{O}$ were added and then incubated for 72 hours at $37^{\circ} \mathrm{C}$ for the growth of Plasmodium in a candle jar. Parasite-infected red blood cells were cultured in a culture flask containing $10 \mathrm{ml}$ complete medium (10\% serum) with $1.5 \%$ final hematocrit. Parasite culture was carried out in LAF (Laminar Air Flow) under a sterile condition and then incubated in $\mathrm{CO}_{2}$ environment at $37^{\circ} \mathrm{C}$. The medium was replaced every 24 hours. Synchronization was undertaken to obtain a ring stage. Parasite culture was added with $5 \%$ sorbitol and centrifuged at $1500 \mathrm{rpm}$ for 10 minutes. The supernatant was discarded, and parasite sediment was soaked in sterile 5\% sorbitol as much as threefold parasite volume and left at room temperature for 10 minutes. The parasite was then washed through centrifugation, and after addition of complete medium with fivefold volume, parasite sediment containing only ring-stage parasites was obtained and returned to the culture flask. Extracts of E. valerianifolia was mixed with $100 \mu$ lof DMSO and RPMI 1640 to acquire $1 \mathrm{ml}$ volume (stock) and then diluted with RPMI. The selected microculture plate had 96 wells, and each well was filled with $100 \mu$ of complete medium containing parasites with $1.5 \%$ hematocrit and $2 \%$ parasitemia. Sample solution was prepared using a $100 \mu \mathrm{l}$ micropipette, and each concentration was transferred into the wells from low to high respective concentrations. Microculture was placed in a vacuum desiccator with a candle jar. The desiccator was sealed exactly at the time of extinguished flame and then incubated in $\mathrm{CO}_{2}$ incubator at $37^{\circ} \mathrm{C}$ for 72 hours. After incubation, the microplates were removed from the candle jar. The test preparation was homogeneously mixed and centrifuged, the filtrate was removed, and the concentrated part was made into smear preparation. The smear was dried at room temperature, and fixation was conducted with $80 \%$ methanol. After drying, the smear was stained with $10 \%$ giemsa solution in distilled water for 30 minutes. 
$\%$ Parasitemia $=$ control parasitemia - drug parasitemia/ control parasitemia x $100 \%$

$\mathrm{IC}_{50}$ values were obtained through probit analysis (5 inhibitions vs $\log$ dose). Here, chloroquine was used as a positive control. ${ }^{31-33}$

Cytotoxic activity. This colorimetric assay is based on the capacity of mitochondria succinate dehydrogenase enzymes in living cells to reduce the yellow water soluble substrate 3(4,5-dimethylthiazol2-yl)-2,5-diphenyltetrazolium bromide (MTT) into an insoluble, colored formazan product which is measured spectrophotometrically. Since reduction of MTT can only occur in metabolically active cells, the level of activity is a measure of viability of the cells culture. Prior to use in the assay, the cells were grown to $80-90 \%$ confluence and synchronized by incubation in the assay media for $4 \mathrm{hrs}$. Cell suspensions $\left(5 \times 10^{3}\right.$ cells $/ 100 \mu \mathrm{l} /$ well $)$ were then incubated with various concentrations $(12.5,25,50$, $100,200,400 \mu \mathrm{g} / \mathrm{ml})$ of plant extract solutions for 24 hrs with a final DMSO concentration of $0.1 \%$. The cells were seeded in 96-well plates. Each concentration was seeded and triplicate plates were used the cell line. Then, the cells were incubated at $37^{\circ} \mathrm{C}$. After $24 \mathrm{hrs}$ incubation, cell viability was determined by adding (Sigma) tetrazolim salt as cytotoxicity indicator, so after 24 hrs of incubation, $15 \mu \mathrm{l}$ of MTT $(5 \mathrm{mg} / \mathrm{ml})$ in phosphate buffered saline (PBS) was added to each well and incubated at $37^{\circ} \mathrm{C}$ for $4 \mathrm{hrs}$. The medium with MTT was then flicked off and the formed formazan crystals were solubilized in $100 \mu \mathrm{l}$ of DMSO and then measured the absorbance at $570 \mathrm{~nm}$ using micro plate reader. Tetrazolium salts are cleaved to formazan dye by cellular enzymes (only in the viable cells). ${ }^{34}$ The percent viability was calculated by using formula:

$\%$ viability $=($ treatment cell count - blank $/$ no treatment cell count-blank) $\times 100 \%$

The concentration that results in $50 \%$ inhibition $\left(\mathrm{IC}_{50}\right)$ value of the extracts were calculated from the equation of the logarithmic line determined by fitting the best line to the curve formed from the data using Microsoft Excel and probit.

\section{RESULTS AND DISCUSSION}

Extraction of $\boldsymbol{E}$. valerianifolia. The yield of $n$ hexane, dichloromethane, ethyl acetate and methanol extracts was as much as $42.9 \mathrm{gm}(1: 43 \% \mathrm{w} / \mathrm{w}), 21.4$ gm $(0.71 \% \mathrm{w} / \mathrm{w}), 29 \mathrm{gm}(0.97 \% \mathrm{w} / \mathrm{w})$ and $135.8 \mathrm{gm}$ (3:53\% w/w), respectively. The highest amount was found in the polar methanolic extract.

Antibacterial and antifungal activities. Gram positive bacteria (Stap. aureus, MRSA and B. cereus) and gram negative bacteria (E. coli and $P$. aeruginosa) were used as antibacterial test microorganisms, while $C$. albicans became the antifungal test microorganism. The results of antibacterial and antifungal activities at $1000 \mathrm{ppm}$ showed that the four extracts did not have activity more than the positive control amoxicillin for antibacterial and ketoconazole for antifungal activity against tested microorganisms. No zone of inhibition appeared in extracts when compared with the positive control through diffusion method (Table 2). Minimum Inhibitory Concentration (MIC) indicates that the administration of maximum concentration of $1000 \mathrm{ppm}$ in E. valerianifolia extracts were invisible in inhibition zones. In addition, the limited number of research on E. valerianifolia could not confirm which compound is responsible for antagonism in antibacterial and antifungal test. The most recent study of the genus Erechtites revealed that $E$. hieracifolia contains hieracifoline and jacobine alkaloids yet failed to provide antibacterial and antifungal effects. ${ }^{35,36}$

Antiplasmodium activity. Probit analysis was used to determine the $\mathrm{IC}_{50}$ values using chloroquine as the positive control. $\mathrm{IC}_{50}$ is the concentration at which $50 \%$ of $P$. falciparum is inhibited then classified as having high activity for concentration of $\mathrm{IC}_{50} \leq 10 \mu \mathrm{g} / \mathrm{ml}$, moderate activity for $10-50 \mu \mathrm{g} / \mathrm{ml}$, and low activity for $>50 \mu \mathrm{g} / \mathrm{ml}$. 37,38

The results of in vitro antiplasmodium activity test with probit analysis showed that $\mathrm{IC}_{50}$ of ethyl acetate extract was $117.122 \mu \mathrm{g} / \mathrm{ml}$ and considered the best among other extracts. The activity of the four extracts of $E$. valerianifolia was lower than chloroquine as the positive control with $\mathrm{IC}_{50}$ of 1.114 
$\times 10^{-3} \mu \mathrm{g} / \mathrm{ml}$. The results of antiplasmodium test of the four extracts were lower than the positive-control (chloroquine) because the extract might consist of various components possibly encouraging a mechanism of antagonism compared to single compounds. The in vitro antiplasmodium test results were shown in table 1 . In addition, since research on E. valerianifolia remains limited there has been no confirmation as to which compound causes antagonism in antiplasmodium test. The latest research on the genus Erechtites was on Erechtites hieracifolia that contains hieracifoline and jacobine alkaloids but still provided no information about antiplasmodium activitiy. ${ }^{35,36}$ However, different species might contain different compounds.

Table 1. $\mathrm{IC}_{50}$ of $E$. valerianifolia extracts on Plasmodium falciparum FCR3.

\begin{tabular}{ll}
\hline Extract & $\mathrm{IC}_{50}(\mu \mathrm{g} / \mathrm{ml})$ \\
\hline$n$-Hexane extracts & 183.979 \\
Dichloromethane extracts & 554.719 \\
Ethyl acetate extracts & 117.122 \\
Methanol extracts & 373.424 \\
Chloroquine & $1.114 \times 10^{-3}$ \\
\hline
\end{tabular}

Table 2. $\mathrm{IC}_{50}$ of four extracts of $E$. valeranifolia against Hela, WiDr, and MCF-7 cell lines.

\begin{tabular}{llll}
\hline \multirow{2}{*}{ Extract } & \multicolumn{3}{l}{$\mathrm{IC}_{50}(\mu \mathrm{g} / \mathrm{ml})$} \\
\cline { 2 - 4 } & Hela & WiDr & MCF-7 \\
\hline n-Hexane & 3,096 & 3,779 & 10,159 \\
\hline Dichlormetane & 4,639 & 1,848 & 3,800 \\
\hline Ethyl acetate & 12,281 & 11,762 & 0,015 \\
\hline Methanol & 1,614 & 3,415 & 6,406 \\
\hline $\begin{array}{l}\text { 5-Flurouracil } \\
\text { (control) }\end{array}$ & 4,186 & 0,000 & 0,353 \\
\hline
\end{tabular}

Cytotoxicity. These activities were analyzed by monitoring cell viability of treated and untreated cells by their reduction of the tetrazolium substrate, MTT. Cell line used were MCF-7, Hela and WiDr. Generally, cytotoxity test showed $\mathrm{IC}_{50}$ of extract for E. valeranifolia which was better activity than positive control (5-fluorouracil). Profiles obtained from cell viability MTT test were shown in table 2 . Bioactivity screening of four extract E. valeranifolia showed to have potential chemopreventive activity $\left(\mathrm{IC}_{50}<30 \mu \mathrm{g} / \mathrm{ml}\right)$. To be a good drug candidate, the $\mathrm{IC}_{50}$ value of such agent should be sufficiently low to avoid any possible unspecific effects. The American National Cancer Institute assigns a significant cytotoxic effect of promising anticancer product for future bioguided studies if it exerts an $\mathrm{IC}_{50}$ value $<30$ $\mu \mathrm{g} / \mathrm{ml}^{39}{ }^{39}$ In this preliminary study, we have focused our interest on crude plant extracts for bioactivity screening, the cytotoxic activity could be due to the presence of active products that could probably have increasingly anti-growth effects. The $\mathrm{IC}_{50}$ of four extracts of $E$. valeranifolia were found to be significant in every cell line, when compared to positive control. This study provides an important basis for further investigation into the isolation, characterization and mechanism of cytotoxic compounds from the screened medicinal plant. Thus, this plant could be a source of new lead structures in drug design for cancer treatment. In addition, further studies are required to elucidate the precise molecular mechanisms and targets for cell growth inhibition which will allow the rationale design for more effective molecules for eventual use as cancer chemopreventive and/or therapeutic agents.

\section{CONCLUSION}

For gram positive bacteria (Stap. aureus, (Methicillin-resistant Stap. aureus and B. cereus) and gram negative bacteria (E. coli and $P$. aeruginosa) as test microorganisms as well as $C$. albicans as antifungal test microorganism, the four extracts at a concentration of maximum $1000 \mathrm{ppm}$, demonstrated no activity. The in vitro antiplasmodium FCR3 test with probit analysis demonstrated $\mathrm{IC}_{50}$ of ethyl acetate extract as $117.12 \mu \mathrm{g} / \mathrm{ml}$ and was considered the best among other extracts. Compared to the positive-control chloroquine with $<50 \mu \mathrm{g} / \mathrm{mlof} \mathrm{IC}_{50}$, the four extracts of $E$. valerianifolia possessed lower activity. The results showed that the four extracts showed good cytotoxic activity on MCF 7, WiDr and Hela cell lines with $\mathrm{IC}_{50}<30 \mu \mathrm{g} / \mathrm{ml}$, when they were compared with 5 -fluorouracil as positive control. 


\section{ACKNOWLEDGEMENTS}

We are grateful to Pharmacology and Parasitology Laboratory, Faculty of Medicine and Faculty of Pharmacy, Gadjah Mada University, Yogyakarta Indonesia for antibacterial, antifungal, antiplasmodium and cytotoxic tests. Specially we thanks the Ministry of Research and Directorate Higher Education, Republic of Indonesia for foundation of this research by Doctoral Desertation Programme.

\section{REFERENCES}

1. Dewoto HR. 2007. Development of indonesian traditional medicine became phytopharmaca, Indonesian Med. Maga. 57, 205-211

2. Umiyah. 2011. Utilization of some wild plants (Weeds) as vegetables in jember district, Berk. Penel. Hayati. 17, 103107

3. Audu, S.A., Taiwo, A.E., Ojuolape, A.R., Sani, A.S., Bukola, A.R. and Mohammed I.A. 2012. Study review of documented phytochemistry of amygdalina (Family Asteraceae) activity of plant extract. J. Natu. Sci. Res. 2, 7

4. Becker, J.V.W., Merwe, M.M.V.D., Brummelen, A.C.V., Pillay, P., Crampton, B.G., Mmutlane, E.M., Parkinson, C., Heerden, F.R.V., Crouch, N.R., Smith, P.J., Mancama, D.T. and Maharaj V.J. 2011. In vitro anti-plasmodial activity of Dicoma anomala subsp. gerrardii (Asteraceae): identification of its main active constituent, structure-activity relationship studies and gene expression profiling. Malaria J. 10, 295.

5. Bero, J., Richb, MF and Quetin-Leclercq J. 2009. Antimalarial compounds isolated from plants used in traditional medicine, J. Pharm. Pharmacol. 61, 1401-1433.

6. Hernandez, J., Bracho, I., Rojas-Fermin, L.B., Usubillaga, A. and Carmona J. 2013. Chemical composition of the essential oil of Erechtites Valerianifolia from Merida, Venezuela, Nat. Prod. Commun. 8, 1477-1478.

7. Wahab, N.A., Kong, K.W., and Ismail A. 2015. Nutritional values and bioactive components of under-utilised vegetables consumed by indigenous people in Malaysia. Sci. Food Agric. 9, 2704-2711.

8. Haque, M.d.E., Sultana, A., Shibib, B.A. and Islam, M. M. 2012. Antimicrobial, antioxidant and cytotoxic activities of Callistemon citrinus (Curtis) Skeels. Dhaka Univ. J. Pharm. Sci. 11, 51-54.

9. Djide dan Sartini. 2008. Basic Pharmaceutical Microbiology, Lephas, Makasar.

10. Radji M. 2011. crobiology. Medicine Book, ECG, JakartaIndonesia.
11. Bramono $\mathrm{K}$ and Budimulja U. 2005. Epidimiology of onychomycosis. In: Indonesia, data obtained from three individual studies. Jpn. J. Med Mycol. 46, 171-176.

12. Centers for Disease Control and Prevention. 2012. Where Malaria Occurs. Available from URL: http://www.cdc.gov/ malaria/about/distribution.html. Accessed September 29

13. Directorate of Animal-Source Disease Control. 2011. Epidemiology in Indonesia. Bulletin Window Data and Health Information. 1, 1-16.

14. World Health Organization. Malaria, Available from URL: http://www.who.int/topics/malaria/en/. Accessed August 9, 2017

15. World Health Organization. 2017. Guidelines for the Treatment of Malaria. $3^{\text {rd }}$ edition, available from URL: http://apps.who. int/iris/bitstream/10665/162441/1/97892415 49127_eng.pdf. Accessed August 9.

16. Bunnag D, Kanda T, Karbwang J, Thimasarn K, Pungpak S. 1997. Two doses of artemether/mefloquine or artesunate/mefloquine combination for multidrug resistant falciparum malaria. Southeast As. J. Trop. Med. Pub. Health. 28, 727-35

17. Syamsudin. 2005. The antimalarial drugs mechanism. $J$. Pharm. Sci. Indonesia 3, 37-40.

18. World Health Organization. 2017. Antimalarial drug combination therapy report of a WHO technical consultation, available from URL: Error! Hyperlink reference not valid.. Accessed August 9

19. Aguiar, A.C.C., Rocha, E.M.M., Souza, N.B., França, T.C.C. and Krettli A.U. 2012. New approaches in antimalarial drug discovery and development - A review. Mem. Inst. Oswaldo. Cruz. 107, 831-45.

20. Beourou, S, Le Lamer, A.C., Maurel-Chevalley, S., Mutiso, P.B.C., Souard, F., Moulis, C., Fabre, N. and Valentin, A. 2011. Evaluation of the antiplasmodial activity of extracts of plants used in traditional medicine in Kenya. Brazilian $J$. Pharmacol. 21, 986-90.

21. Chinchilla, M., Valerio, I., Sanchez, R., Mora, V., Bagnarello, V., Martinez, L., Gonzalez, A., Vanegas, J.C. and Apestegui A. 2012. In vitro antimalarial activity of extracts of some plants from a biological reserve in costa rica. Rev. Biol. Trop. (Int. J. Trop. Biol.) 60, 881-91.

22. Culvenor, C.C.J and Smith, D.C. 1955. The alkaloids of Erectites quadridentata D.C. Australian J. Chem. 8, 556561.

23. Lemos, T.G., Monte, F.J.Q., Machado, M.I.L., Parente, L.L. and Campos, T.A. 1998. Essential oil of Erechtites hieracifolia, J. Essen. Oil Res. 10, 217-218.

24. Lorenzo, D., Saavedra, G., Loayza, I. and Dellacassa, E. 2001. Composition of the essential oil of Erechtites hieracifolia from Bolivia, Flavour Fragr. J. 16, 353-355.

25. Manske, R.H.F. and Holmes, H.L. 1950. The alkaloids: chemistry and physiology Volume 1, Academic Press Ins Publisher New York.. 153-155. 
26. Saxena, S., Pant, N., Jain, D.C. and Bhakuni, R.S. 2003. Antimalarial agents from plant sources. Curr. Sci. 85: 13141329.

27. Wright $\mathrm{a}^{\mathrm{a}}$, C.W. 2005. Traditional antimalarials and the development of novel antimalarial drugs. J. Ethnopharmacol. 100, 67-71.

28. Wright ${ }^{\text {b }}$, C.W. 2005. Plant derived antimalarial agents: New leads and challenges. Phytochem. Rev. 4, 55-61.

29. Riyanto, S. 2003. Phytochemical studies and bioactivity tests of Muraya Paniculata Jack, Aegle Marmelos Correa, and Zingiber Amaricans Blume, Thesis, Doctor of Philosophy Universiti Putra Malaysia.

30. Tortora, G.J., Funke, B.R. and Case, C.L. 2001. Microbiology: An Introduction, Benjamin Cummings, San Francisco.

31. Desjardins, R.E., Canfield, C.J., Haynes, J.D. and Chulay, J.D. 1979. Quantitative assessment of antimalarial activity in vitro by a semiautomated microdilution technique. Antimicrob. Agents Chemother. 16, 710-18.

32. Gessler, M.C., Nkunya, M.H.N., Nwasumbi, L.B., Heinrich, M. and Tonner, M. 1994. Screening tanzanian medical plants for antimalarial activity. Acta Tropica. 55, 65-67.
33. Vejanan V, Latip J, Chin LP, Embi N, and Sidek HM. 2012. in vitro and in vivo anti-plasmodial activities of Gynura procumbens. Sains Malaysiana 41, 1535-1542.

34. Mosmann T. 1983. Rapid colorimetric assay for cellular growth and survival : application to proliferation and cytotoxicity assays. J. Immunol. Meth. 65, 55-63.

35. Adams, R and Gianturco, M. 1956. Senecio alkaloids, the Composition of "Hieracifoline" and "Jacobine". J. Am. Chem. Soc. 78, 398-400.

36. Manske RHF. 1939. The alkaloids of Senecio species: IV. Erechtites hieracifolia (L.) Raf. Canadian J. Res.17b: 8-9.

37. Fidock, D.A., Rosenthal, P.J., Croft, S.L., Brun, R. and Nwaka, S. 2004. Antimalarial drug discovery : Efficacy models for compounds screening. Nature Reviews Drug Discovery. 3, 509-520.

38. Sha'a KK, Oguche S, Watila IM, Ikpa TF. 2011. In vitro antimalarial activity of the extracts of Vernonia amygdalina commonly used in traditional medicine in Nigeria. Sci. World J. 6, 5-9.

39. Suffness M, and Pezzuto JM. 1990. Assays related to cancer drug discovery (Eds. Hostettmann, K.) Methods in Plant Biochemistry: Assays for Bioactivity, Academic Press, London, pp. 71-133. 